\title{
Papel de las células dendríticas tolerogénicas ILT3+/ILT4+ en la respuesta inmunitaria a trasplante de órganos y tejidos
}

\author{
John F. Arboleda, Luis F. García, Cristiam M. Álvarez \\ Grupo de Inmunología Celular e Inmunogenética, Facultad de Medicina, Instituto de Investigaciones Médicas, \\ Universidad de Antioquia, Medellín, Colombia
}

\begin{abstract}
Las células dendríticas son las células presentadores de antígeno más potentes y, por lo tanto, son importantes en el desencadenamiento de la respuesta inmunitaria frente a aloantígenos; sin embargo, también juegan un papel fundamental en el mantenimiento de la tolerancia periférica. La tolerancia es potenciada por la expresión en estas células de los receptores inhibidores ILT3 e ILT4, los cuales, mediante el reclutamiento de fosfatasas de tirosinas a sus dominios ITIM, inhiben la activación de la célula presentadora de antígeno y conducen a una débil respuesta de la célula T. Estos receptores propician, además, una interacción bidireccional con células T supresoras, T reguladoras o ambas, generando una cascada inmunorreguladora específica de antígeno, en la cual la célula dendrítica se comporta como una célula "tolerogénica".

En esta revisión analizamos la biología y el comportamiento de las células dendríticas tolerogénicas que expresan altos niveles de ILT3 e ILT4, así como algunos aspectos moleculares y genéticos de estos receptores y su importancia en la modulación de las respuestas inmunitarias específicas de aloantígeno frente a un trasplante.
\end{abstract}

Palabras clave: trasplante, células dendríticas, tolerancia inmunológica, inmunomodulación, supervivencia.

\section{$\mathrm{ILT3}^{+} / \mathrm{ILT}^{+}$tolerogenic dendritic cells and their influence on allograft survival}

Dendritic cells, the most powerful antigen-presenting cells, are important for triggering of the immune responses to allo-antigens. However, they also play a fundamental role in the peripheral tolerance maintenance. Tolerance is enhanced by the presence on the dendritic cell surface of the inhibitor receptors ILT3 and ILT4. They recruit protein tyrosine-phosphatases to their ITIM domains and inhibit antigen-presenting cell activation, leading $T$ cell hypo-responsivensess. Moreover, these receptors favor a bidirectional interaction with T-suppressor and T-regulator cells, generating an antigen-specific immunoregulator cascade, in which the dendritic cell behaves as a tolerogenic cell. In the current review, analysis is centered on the biology and behavior of the tolerogenic dendritic cells that express high levels of ILT3 and ILT4. Some molecular and genetics aspects of these receptors are discussed as well as their importance in the modulation of the allo-specific antigen immune response to transplants.

Key words: Transplantation, dendritic cells, immune tolerance, immunomodulation, survival

El trasplante de órganos y de tejidos es la solución terapéutica para la mayoría de las enfermedades crónicas terminales y algunas neoplasias. Sin embargo, una vez el órgano ha sido trasplantado, se requiere de tratamiento inmunosupresor para impedir la activación del sistema inmunitario frente al aloinjerto. Estos tratamientos se basan en el uso de fármacos inmunosupresores que

$\overline{\text { Correspondencia: }}$

Cristiam M. Álvarez, Grupo de Inmunología Celular e Inmunogenética, Sede de Investigación Universitaria (SIU), Universidad de Antioquia, Carrera 53 №. 61-30, laboratorio 410, Medellín, Colombia

Teléfono: (+574) 219 6448; fax: (+574) 2196455

cristianma@medicina.udea.edu.co

Recibido: 05/08/10; aceptado:10/02/11 bloquean la activación del sistema inmunitario, conduciendo así a múltiples efectos secundarios, como el incremento de la incidencia y seriedad de infecciones y neoplasias (1). Para minimizar estos efectos, la inmunología de trasplantes se ha enfocado en el estudio de la tolerancia específica de antígeno $(2,3)$.

La tolerancia se define como el estado en el cual el sistema inmunitario, de forma activa, regula negativamente la respuesta efectora frente a antígenos específicos. Uno de los principales mecanismos implicados en la inducción y el mantenimiento de la tolerancia inmunológica a los trasplantes es la anergia, en la cual se da un estado de débil respuesta específica de antígeno, pero con respuesta normal frente a otros antígenos 
(4). Para la anergia es de fundamental importancia la sinapsis entre las células presentadoras de antígeno y las células $\mathrm{T}$, pues durante el contacto de estas dos células se dictan las señales para una adecuada activación de las células $\mathrm{T}$ o para el inicio de un estado de débil respuesta de estas mismas con respecto a un antígeno específico (3).

Lascélulaspresentadorasdeantígenoporexcelencia son las células dendríticas, las cuales juegan un papel central en la iniciación de la inmunidad y la tolerancia $(2,5)$. Existen diferentes mecanismos por los cuales estas células pueden inducir tolerancia. En uno de ellos, las células dendríticas inmaduras, que expresan bajos niveles de moléculas del complejo mayor de histocompatibilidad $(\mathrm{CMH})$ de clase II y moléculas coestimuladoras, pueden inducir tolerancia en las células $T$, mientras las células dendríticas maduras, que expresan altos niveles de esas moléculas, inducen inmunidad (6). Las células dendríticas semimaduras pueden ser fenotípicamente maduras, pero tienen una capacidad reducida para producir citocinas proinflamatorias (7). Además, se ha sugerido que la calidad de la interacción entre la célula T y la célula dendrítica es importante, pues un contacto estable favorece la activación de la célula $T$, mientras que los contactos breves contribuyen notablemente a la inducción de la tolerancia de la célula T (8).

También, se han descrito los receptores inhibidores ILT-3 e ILT-4 pertenecientes a la familia de receptores ILT (Immunologlobulin-Like Tanscripts). Cuando son expresadas por células dendríticas, estas moléculas potencian notablemente la inducción de tolerancia mediante la interacción con células $T$ supresoras y $T$ reguladoras (9). La información acumulada durante los últimos años muestra que este fenómeno es relevante en la inmunología de trasplantes y la biología de las células dendríticas que participan en la inducción de tolerancia. Algunos términos usados en inmunología de trasplantes, inmunorregulación y biología de células dendríticas empleados en esta revisión, se presentan en el cuadro 1.

\section{Biología de las células dendríticas}

Durante los últimos 35 años, después de las primeras observaciones realizadas por Steinman y Cohn en 1973 (10), las células dendríticas han sido ampliamente documentadas y se han convertido en objetivo central de estudios sobre la respuesta inmunitaria innata y adaptativa, así como sobre el mantenimiento de la tolerancia central y periférica (11).
Se han descrito dos subpoblaciones principales de células dendríticas: las células dendríticas convencionales (conventional Dendritic Cells, CDC), derivadas de precursores mieloides, caracterizadas por el fenotipo LIN 1;, CD11 chigh, HLA DR ${ }^{+}, C D 123^{-1 / o w} ; y$ las células dendríticas plasmocitoides (plasmacitoid Dendritic Cells, pDC), derivadas de precursores linfoides, las cuales exhiben el fenotipo LIN 1; CD123 high, HLA DR ${ }^{+}$, CD11C $^{\text {-low }}(12,13)$.

Las subpoblaciones de células dendríticas circulantes pueden ser identificadas también mediante un panel de anticuerpos monoclonales: BDCA-1 (CD1C), expresado específicamente en las CDC, y el BDCA-2 (una lectina II de tipo C), expresada específicamente en las pDC (14). En sangre, los porcentajes de estas dos poblaciones celulares son muy bajos, aproximadamente, 0,22 \% y 0,05 $\%$ de las células mononucleares, respectivamente (15).

El nombre de células dendríticas plasmocitoides se deriva de su similitud morfológica con las células plasmáticas secretoras de inmunoglobulinas, pero al igual que las CDC, se derivan de precursores de medula ósea CD34+ (14). Las CDC se han subdividido en CDC migratorias y CDC residentes de tejidos linfoides. Las CDC migratorias son las centinelas de los tejidos no linfoides y migran a los ganglios linfáticos después de encontrar un estímulo inflamatorio, aunque esta migración también ocurre en menor nivel en condiciones de reposo de la célula dendrítica. Las células dendríticas residentes de tejidos linfoides capturan el antígeno directamente dentro de estos órganos y a este grupo pertenece la gran mayoría de células dendríticas del timo, bazo y ganglios linfoides $(16,17)$.

Las células dendríticas migratorias y residentes de tejidos linfoides pueden también subdividirse. Para las migratorias, la división se basa en el tejido de origen, por ejemplo, las células de Langerhans que están localizadas en la piel, mientras que, para las residentes en tejidos linfoides, se basa en la expresión de marcadores particulares y específicos de esos tejidos $(18,19)$.

Por su parte, las pDC son productoras de interferones de tipo I y pueden estar presentes tanto en sangre como en órganos linfoides (20). En reposo, las pDC pueden clasificarse como prepDC (16), pero una vez se activan, adquieren la capacidad para producir grandes cantidades de interferones de tipo I y pueden presentar algunas 
propiedades de procesamiento y presentación de antígeno $(21,22)$. Se creía que las células dendríticas derivadas de los precursores mieloides inducían sólo respuestas de tipo Th1, mientras que las de origen linfoide inducían sólo respuestas de tipo Th2, pero se ha demostrado que las pDC de origen linfoide también pueden inducir respuestas de tipo Th1 después de la activación con algunos virus o con CD40 $(23,24)$.

Las células dendríticas precursoras y las células dendríticas inmaduras migran desde la médula ósea hacia los tejidos periféricos, donde encuentran el antígeno. Tienen una gran capacidad endocítica y expresan una variedad de receptores para la captura de antígenos, incluyendo Fc $\gamma$ Rs, CD32 y CD64, los receptores de IgE FceRI y FceRII, los receptores del complemento CD11b y CD11c, DEC205, un receptor de unión a manosa de tipo lectina-C, variedad de receptores de tipo toll o TLR, la molécula DC-SIGN (Dendritic Cell-Specific Intercellular Adhesion Molecule-3-Grabbing Non-Integrin) o CD209 y receptores scavenger para células apoptóticas como $a_{v} \beta_{5}$ y CD36 (25). Durante el proceso de maduración, estos receptores les permiten a las células dendríticas capturar eficientemente todo tipo de antígenos, tales como bacterias, virus, células muertas, proteínas y complejos inmunitarios, para procesar las proteínas y convertirlas en péptidos (26-28).

Los antígenos adquiridos del medio extracelular son típicamente expresados en las moléculas $\mathrm{CMH}$ de clase II, mientras que los endógenos de compartimentos del citosol son expresados por las moléculas $\mathrm{CMH}$ de clase I. Además de estas vías clásicas, algunos antígenos exógenos pueden escapar de la vía endocítica (por ejemplo, por fagocitosis de células apoptóticas), ser degradados por el proteasoma y cargados en las moléculas $\mathrm{CMH}$ de clase I, fenómeno que se conoce como "presentación cruzada" (29).

Los complejos péptido-moléculas $\mathrm{CMH}$ son expresados en la superficie de las células dendríticas para su reconocimiento por la célula $T$ antígeno-específica. Esta interacción entre la célula dendrítica y la célula $T$ genera una superficie de contacto, que se conoce con el nombre de "sinapsis inmunológica" la cual facilita la producción de dos señales necesarias para la activación de ambas célula: la señal 1 mediada por el receptor de la célula T, TCR ( $T$ Cell Receptor) y las moléculas del $\mathrm{CMH}$ (TCR-MHC), y la señal 2 , o señal coestimuladora (30).
Durante el proceso de maduración, las células dendríticas migran desde los tejidos periféricos hacia las áreas ricas en células $T$ en los órganos linfoides, como el bazo, los ganglios linfáticos y el tejido linfoide asociado a las mucosas, donde completan su maduración (26). Uno de los eventos fundamentales en la maduración de células dendríticas es la translocación nuclear del factor de

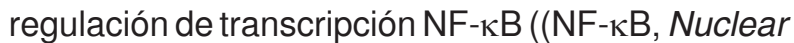
Factor kappa B), el cual regula la expresión de muchos genes que codifican proteínas relacionadas con la respuesta inmunitaria (31).

La maduración completa de las células dendríticas está asociada a la expresión de moléculas de adhesión celular y moléculas coestimuladoras, como CD80 y CD86, cuyos ligándos en la célula T son CD28 y CTLA-4 (CD152), dos miembros de la superfamilia de las inmunoglobulinas, los cuales compiten por afinidad con estas moléculas, y el último muestra mayor afinidad por ellas con capacidad de iniciar una regulación negativa de la respuesta inmunitaria (32).

Además, en las células dendríticas se expresan otras moléculas, como CD40 y OX40L, ambas pertenecientes a la familia de los factores de necrosis tumoral (FNT), que también exhiben funciones y propiedades coestimuladoras y cuyos ligandos en las células T son CD40L y OX40, respectivamente (2).

En la señal 1, la unión del TCR del linfocito T con el complejo $\mathrm{CMH}$-péptido expresado en la células presentadoras de antígeno, promueve la fosforilación de la cadena $\zeta$ del TCR, iniciando la señalización temprana mediada por la actividad de proteínas tirosinas cinasas (Protein Tyrosine Kinase, PTK). Esta onda temprana de fosforilación de las PTK conduce a la activación de vías de señalización, incluyendo incrementos en el flujo de calcio intracelular, la proteína cinasa C (Protein Kinase $C$, PKC), el factor nuclear $\kappa \mathrm{B}$ (NF-кB, Nuclear Factor kappa B) y la activación de las proteínas cinasas activadas por mitógenos (Mitogen Activated Protein Kinases, MAPK). Esas vías activan factores de transcripción que finalmente conducen a la expresión de genes que controlan la respuesta celular específica (33).

La segunda señal está dada por la interacción entre las moléculas coestimuladoras, presentes en la membrana de la célula presentadora de antígeno activada, tales como B7 (B7-1 y B7-2, que corresponden a CD80 y CD86, respectivamente), CD40 y OX40L, con sus respectivos receptores 
CD28 y CTLA-4, CD40L (CD154) y OX40 en la membrana de la célula $T$. En conjunto, la unión del TCR y del CD28 a sus respectivos ligandos, permite la activación de los factores de transcripción NF-кB, NF-AT (Nuclear Factor of Activated T-cells)y AP-1b (Activator Protein 1) en células $T$, iniciando la activación de numerosos genes involucrados en la respuesta inmunitaria, tales como citocinas (principalmente, interleucina (IL) 2 o IL-2), quimiocinas y las mismas moléculas coestimuladoras. Además, la ligación de CD40 en la célula presentadora de antígeno regula positivamente la expresión de moléculas CD80 y CD86, lo cual inicia una retroalimentación positiva que, finalmente, contribuye a la expansión de las células T (34).

\section{Papel de las células dendríticas en la respuesta frente al aloinjerto}

En el contexto del trasplante alogénico, se han identificado dos vías para el reconocimiento de los aloantígenos, la directa y la indirecta. En la vía directa, las células $T$ del receptor reconocen las moléculas $\mathrm{CMH}$ intactas en las células provenientes del donante, usualmente en las células presentadoras de antígeno. Tanto las células CD8+ como las CD4+ pueden reconocer directamente las moléculas $\mathrm{CMH}$ de clase I y de clase II, respectivamente (35). Esta vía parece ser contradictoria con la visión clásica de autorrestricción por las moléculas propias del $\mathrm{CMH}$ de las células T, puesto que aquí, el alopéptido reconocido es presentado en una molécula $\mathrm{CMH}$ no propia.

Por su parte, la vía indirecta de reconocimiento de los aloantígenos es más representativa de la forma como el sistema inmunitario reconoce típicamente un antígeno. Las células T reconocen los aloantígenos provenientes del donante que han sido procesados y presentados en el contexto de las moléculas del $\mathrm{CMH}$ de las células presentadoras de antígeno propias (36).

Ambos tipos de reconocimiento de los aloantígenos pueden darse por el tráfico de las células presentadoras de antígeno (células dendríticas) a los órganos linfoides del receptor, donde la interacción de ellas con la célula T dicta la respuesta final de éstas a los aloantígenos específicos. La interacción entre células $\mathrm{T}$ y células dendríticas puede resultar en la activación adecuada de la célula T o en la débil respuesta de la misma (3).

Como se mencionó anteriormente, la falta de moléculas coestimuladoras produce la activación incompleta de la célula To su conversión en anérgica. Las células $T$ también pueden ser convertidas en anérgicas si encuentran ligandos (péptidos) para los cuales tienen baja afinidad. Además, las células dendríticas pueden inducir anergia de la célula $T$ por la secreción de citocinas, como IL-10 o el factor de crecimiento transformante (Transforming Growth Factor-Beta, TGF)- $\beta$, que regulan negativamente la respuesta inmunitaria (4).

La anergia puede clasificarse en dos grandes categorías: la anergia clonal y la anergia in vivo. En la anergia clonal se presenta un bloqueo en la activación celular y, en la tolerancia adaptativa, o anergia in vivo, ocurre una inhibición generalizada de las funciones efectoras y de proliferación. La anergia clonal surge de la activación incompleta de la célula T, es decir, una señal fuerte del TCR en ausencia de coestimulación o por la estimulación con un ligando de baja afinidad en presencia de coestimulación. La anergia clonal se observa principalmente en células T previamente activadas y usualmente no resulta en la inhibición de funciones efectoras, sino más bien, en una activación celular incompleta y débil caracterizada por un patrón inusual de citocinas, lo que sugiere un estado básicamente contra la proliferación. La tolerancia adaptativa se inicia a menudo in vivo en células $T$ vírgenes por la estimulación en un ambiente deficiente en coestimulación y se caracteriza por una baja producción de IL-2 (37).

$\mathrm{Si}$ bien en ambos casos hay bloqueo en la producción de IL-2 y en la proliferación, sólo la tolerancia adaptativa se asocia con la inhibición de la producción de otras citocinas (a excepción de IL10); además, parece requerir de la persistencia de antígeno, mientras que en la anergia clonal, la falta de respuesta persiste durante semanas después de la eliminación del antígeno.

Por otra parte, la participación del receptor de inhibición CTLA-4 en la inducción de la anergia es compleja. A pesar de que las moléculas coestimuladoras CD80 y CD86 se expresan en la superficie de la célula presentadora de antígeno y se unen con CD28 en la superficie de la célula T, se ha demostrado, mediante la utilización de ratones deficientes en CTLA-4 y ratones knockout para B-7 y CD28, que un segundo receptor para B7, CTLA-4-, presente en las células $T$ activadas sirve como un regulador negativo de la proliferación y activación de la célula T (38). Aunque CD28 y CTLA-4 son reconocidos por las moléculas $\mathrm{B}-7, \mathrm{CTLA}-4$ tiene mayor afinidad por éstas y su expresión se presenta 
tardíamente después de la activación de la célula T (se ha sugerido que CD28 tiene más afinidad para CD80, mientras que CTLA-4 la tiene para CD86) (39).

Actualmente, en modelos de ratón utilizando la proteína de fusión CTLA-4-lg, se ha logrado establecer que CTLA-4 funciona mediante el bloqueo de la vía coestimuladora CD28/B7. Se ha sugerido que hay una diferencia en la habilidad de unión de cada uno de esos receptores para unirse a dos ligandos diferentes con afinidades variables, lo que sugiere que CTLA- 4 se une a B7 cuando éste se encuentra en bajos niveles de concentración. Por lo tanto, CD28 y CTLA-4 son considerados los receptores coestimuladores críticos que determinan el resultado temprano de la estimulación por el TCR (40-42).

\section{Células dendríticas "tolerogénicas"}

Se ha demostrado que las células dendríticas, las más potentes y eficientes células presentadoras de antígeno, contribuyen a la tolerancia de la célula T. La evidencia se originó en estudios de células dendríticas inmaduras (iDC) presentes en tejidos periféricos en estados de reposo y que, aisladas ex vivo y expuestas a antígenos, en ausencia de completa maduración, estimulaban la regulación negativa de la respuesta inmunitaria y, además, inducían células $\mathrm{T}$ reguladoras (Treg) (42). Posteriormente, emergió el concepto de células dendríticas "tolerogénicas", basado en que estas células pueden comportarse como reguladores negativos de la inmunidad, pues tienen la capacidad de inducir y mantener la tolerancia hacia determinados antígenos (9).

El conocimiento acumulado sobre algunos aspectos de la biología molecular de las células dendríticas sugiere que, in vivo, las propiedades "tolerogénicas" se deben a:

- la habilidad para adquirir y presentar antígenos a células $T$ específicas de antígeno, ya sea por vía directa, indirecta o semidirecta;

- la baja expresión constitutiva de moléculas del $\mathrm{CMH}$ y baja expresión neta de moléculas coestimuladoras, como CD80 y CD86;

- la habilidad para generar, seleccionar o expandir células $\mathrm{T}$ reguladoras aloantígeno-específicas de presentación natural o adaptativa;

- la habilidad de promover apoptosis de células T efectoras;
- la habilidad para responder a células Treg, regulando positivamente la expresión de moléculas inhibidoras, como IL-10 o indolamina 2,3 dioxigenasa;

- la habilidad de migrar a las áreas de células T en los tejidos linfáticos secundarios, mediante la expresión de receptores relevantes de quimiocinas, y

- la longevidad in vivo y resistencia a la muerte mediada por células asesinas naturales (NK, natural killers) o células T (3).

Con el objeto de definir algunas características moleculares más específicas de las células dendríticas "tolerogénicas", se han identificado receptores y moléculas de superficie que permiten relacionar su expresión con los estados funcionales y "tolerogénicos" de estas células.

Cortesini et al., usando microarreglos de ADNc en células dendríticas con potencial "tolerogénico", demostraron la regulación negativa de las moléculas coestimuladoras CD40, CD80, CD86, CD54, CD58, CD43, OX40 ligando y TNRF1; y la regulación positiva de ARNm para IK- $\beta$ épsilon -el cual inhibe la activación del NF-кB-, genes antiapoptóticos IAP-1, FAS soluble y ILRa -receptor antagonista de la interleucina 1-, y los receptores inhibidores ILT2, ILT3 e ILT4 (43).

\section{Receptores inhibidores ILT3 e ILT4}

Los ILT2, ILT3 e ILT4 pertenecen a la familia de receptores inhibidores de tipo inmunoglobulina, los cuales muestran un largo dominio intracitoplásmico que contiene motivos inhibidores basados en residuos de tirosina (Immunoreceptor Tyrosinebased Inhibitory Motifs, ITIMS) (figura 1). Estos receptores median la inhibición de la activación celular mediante el reclutamiento de fosfatasas de tirosinas de tipo SHP-1. La transducción de ILT3 e ILT4 en líneas de células dendríticas resultó en la generación de células presentadoras de antígeno que bloquearon completamente la proliferación de células T aloespecíficas $(44,45)$.

Por otra parte, la expresión de los receptores ILT3 e ILT4 puede potenciarse mediante el tratamiento de células dendríticas mieloides con IL-10, interferón gamma (IFN- $\gamma$ ) o vitamina D3 $(44,46)$. Estas células dendríticas "tolerogénicas" inducen la generación de células $\mathrm{T}$ reguladoras y células $\mathrm{T}$ supresoras, las cuales inhiben la activación del factor de transcripción NF-kB y la transcripción de moléculas coestimuladoras en células presentadoras de 


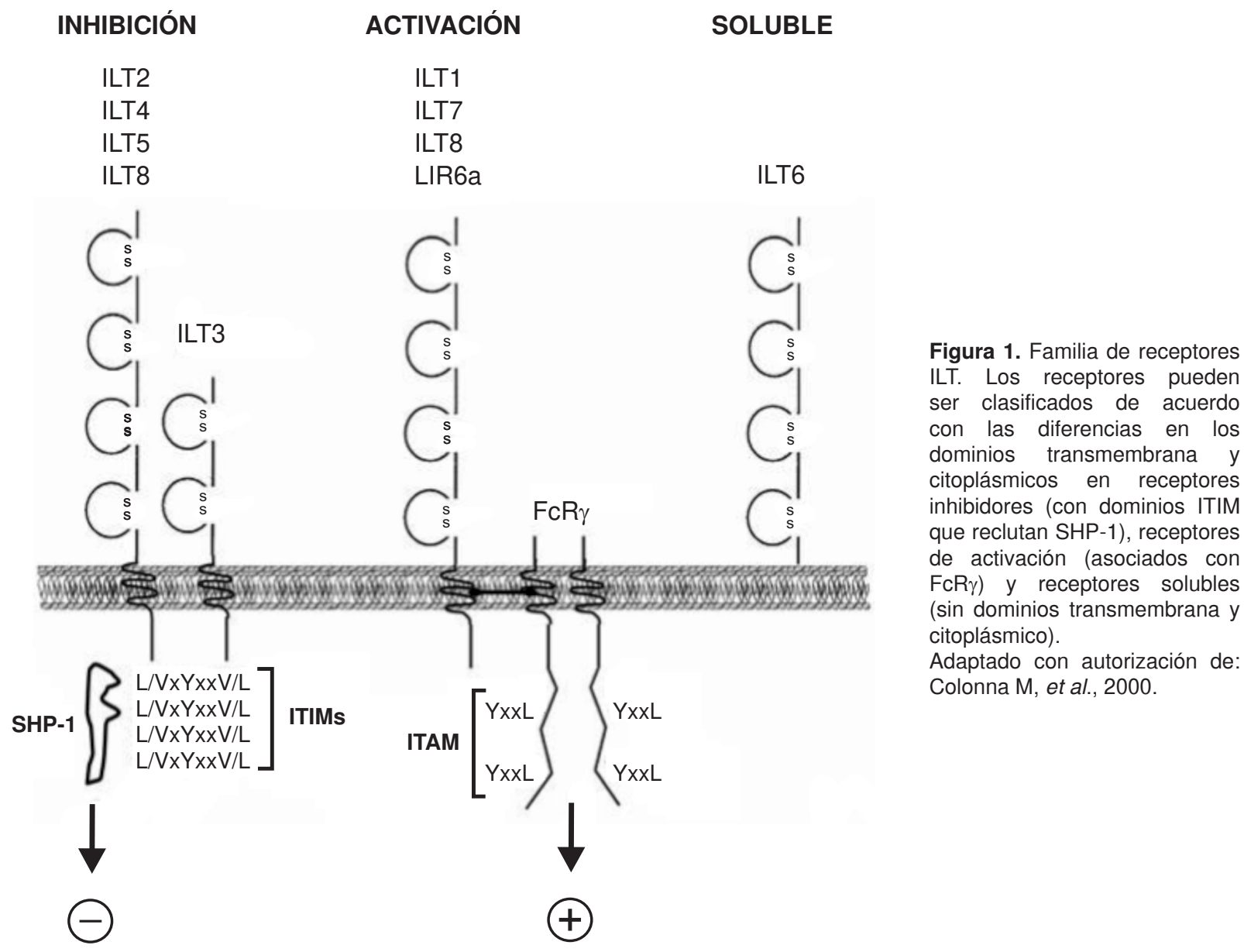

antígeno (47). Así, las células dendríticas con aumento de la expresión de ILT3 e ILT4, inducen la anergia de la célula $\mathrm{T}$ y la expresión de estos receptores en su superficie se convierte en la característica general de las células dendríticas "tolerogénicas" (44).

\section{Aspectos generales}

La inclusión de un receptor inmunológico dentro de la superfamilia de los receptores inhibidores, se basa en la demostración de que éste sea capaz de bloquear la función de los receptores de "activación" inmunológica, entre los cuales se encuentra el TCR, el receptor de la célula B y varios tipos de receptores Fc; además, su función inhibidora puede ser bloqueada con el uso de anticuerpos monoclonales dirigidos contra la porción extracelular del receptor, lo que implica que la interacción de esos receptores requiere de ligandos específicos (48).

La función inhibidora de los miembros de la superfamilia de los receptores inhibidores depende de la presencia de ITIM en el dominio citoplásmico de la molécula (figura 1). La presencia de este dominio en las colas citoplásmicas de algunas moléculas es suficiente como criterio inicial para la identificación de candidatos a receptores inhibidores.

Se han identificado nueve tipos distintos de receptores inhibidores en humanos y cada tipo está representado por uno o más miembros. Estos nueve tipos incluyen dos tipos de receptores inhibidores de tipo lectina-C, que son el CD94NKG2 y NKRP1, y siete diferentes tipos de receptores inhibidores de la superfamilia de las inmunoglobulinas: KIR2D, KIR3D, ILT, GP-49, PIR, LAIR y Fc $\gamma$ RIlb1. Estos receptores inhibidores están distribuidos ampliamente en el sistema hematopoyético humano $\mathrm{y}$, en general, poco se conoce acerca de sus ligandos (49).

Los ILT, también conocidos como receptores LIR (Leukocyte Immunoglobulin-like Receptors) o MIR (Macrophage Immunoglobulin-like Receptors), representan una novedosa superfamilia de receptores inhibidores y activadores involucrados en la vigilancia inmunitaria. 
Se caracterizan por dos o cuatro homodominios de tipo inmunoglobulina C-2 extracelulares y se clasifican en tres grupos por las diferencias en los dominios transmembrana y citoplásmicos (figura 1). El primer grupo incluye los receptores que contienen ITIM, tales como ILT2, ILT3, ILT4, ILT5 y LIR8. Estos receptores inhiben la activación celular por el reclutamiento de proteínas fosfatasas de tirosina SHP-1 $(50,51)$. El segundo grupo se caracteriza por la presencia de una corta cola citoplásmica a la que le faltan motivos de reconocimiento para los mediadores de señalización y por la presencia de residuos básicos de arginina en la región hidrofóbica trasmembrana, tales como ILT1, ILT7, ILT8 y LIR6a. Estos receptores se asocian con la cadena gamma de los receptores $\mathrm{Fc}_{\mathrm{c}}(\mathrm{FcR} \gamma)$, los cuales traducen señales estimuladoras por el reclutamiento de proteínas cinasas de tirosinas mediante el motivo citoplásmico del inmunorreceptor de activación basado en tirosina (ITAM), y, finalmente, el tercer grupo incluye una molécula soluble, ILT6, la cual carece de región trasmembrana y dominios intracitoplásmicos y puede ser secretada en forma de receptor soluble $(52,53)$.

\section{Genética, distribución y regulación}

Genética, estructural y funcionalmente, la familia ILT está estrechamente relacionada con la familia de KIR (Natural Killer Immunoglobulin-like Receptors) $(54,55)$, pues ambos están codificados en la región cromosómica 19q13.4 humana, conocida como el complejo del receptor de leucocitos, donde también se encuentran algunos genes para los receptores Fc de inmunoglobulinas y lectinas de tipo inmunoglobulinas que se unen al acido siálico (56).

Los análisis secuenciales de la región ILT contenidos en cromosomas artificiales bacterianos han revelado la existencia de, al menos, ocho loci distintos para los receptores de la familia ILT y dos seudogenes, lo cual sugiere un sistema poligénico de receptores ILT. Además, los análisis de polimorfismos en ILT han mostrado una variabilidad alélica significativa (57). En el caso específico de ILT3 e ILT4, Papanikolaou et al. reportaron dos polimorfismos de nucleótido único en el dominio 1 (lgD1) de ILT4 en las posiciones 113 y 114. El dominio 1 es parte de la porción distal de ILT4, involucrado en las interacciones proteína-proteína en la sinapsis entre las células presentadoras de antígeno y las células T (58). Recientemente, el mismo grupo demostró que el gen de ILT3 presenta un desequilibrio de ligamiento entre algunos de sus alelos y es muy polimórfico. Es posible que tales variaciones en esta región del cromosoma 19 estén asociadas también con enfermedades autoinmunitarias (59).

Todos los receptores ILT son expresados en monocitos circulantes, en macrófagos y células dendríticas derivadas de monocitos $(60,61)$. Además, ILT1 e ILT5 se expresan en granulocitos, células NK y células T, mientras que ILT2, identificado como CD85 (62), se expresa en células NK, células $T$ y células $B$ periféricas. En la médula ósea la expresión de los receptores inhibidores ILT se incrementa durante la maduración de los linajes de las células $B(62)$ y las células mieloides, mientras que la expresión de receptores ILT de activación se mantiene estable o disminuye ligeramente. En las amígdalas, el receptor inhibidor ILT2 (CD85) se expresa en gran cantidad en células B activadas y células plasmáticas (62). Estas observaciones sugieren que la función de los receptores inhibidores es particularmente importante en el estado final de maduración, cuando las células han adquirido su máxima capacidad efectora (63).

Recientemente se ha observado que algunos ILT se expresan diferencialmente en varias poblaciones de células dendríticas primarias en sangre periférica humana. En particular, se ha demostrado que las células dendríticas se pueden dividir dependiendo de la expresión diferencial de ILT1 e ILT3. Las células ILT1+/ILT3+ muestran marcadores mieloides, como CD33, CD11 y CD13, y exhiben una morfología típica de célula dendrítica. Esta población celular incluye tanto células dendríticas inmaduras (CD1a+) como maduras (CD1a-), las cuales migran de la médula ósea a los tejidos periféricos o de estos a los órganos linfoides secundarios por la sangre. Por otra parte, las células ILT3+/ILT1- no expresan CD33, CD11c y CD13, expresan CD36 a un muy alto nivel y muestran una morfología de tipo célula plasmática (52).

El ILT4, por su parte, conocido también como LIR-2, CD58d, LILRB2 o MIR10 es expresado predominantemente en células mielomonocíticas (64). El ILT2 es expresado principalmente en células mieloides (monocitosycélulas dendríticas) yalgunas células linfoides, incluyendo subpoblaciones de células NK, células T y B; mientras que el ARNm de ILT7 es restringido a pDC. Se ha evidenciado también que la expresión ILT2 e ILT3 es regulada negativamente en pDC activadas y células dendríticas derivadas de monocitos, lo que sugiere 
que la regulación negativa de estos receptores podría contribuir a la activación de las células dendríticas (53).

Durante la diferenciación y maduración de las células dendríticas, la expresión de moléculas coestimuladoras aumenta, lo cual se atribuye al factor NF-kB/Rel, mientras que la expresión de los receptores inhibidores disminuye concomitantemente, lo que facilita el incremento en las propiedades inmunogénicas de la célula dendrítica madura (63).

La regulación de estos receptores está dada principalmente por el factor PU.1, un factor de transcripción hematopoyético de la familia de los factores ets, el cual es requerido tanto para el desarrollo de linajes mieloides como linfoides. La expresión de PU.1 es detectable aún en células madres hematopoyéticas totipotenciales y es regulado positivamente durante la diferenciación mieloide y de las células $B(65,66)$.

Por otra parte, la remodelación de la cromatina está ampliamente involucrada en la modulación del sistema inmunitario y también controla la expresión del locus ILT $(67,68)$. Aunque los mecanismos que controlan la estructura de la cromatina en dicho locus no están bien establecidos, existen regiones que reclutan factores que remodelan la cromatina y afectan la transcripción de las regiones distales de los genes ILT. En estos genes, los elementos reguladores distales, conocidos como regiones controladoras del locus, pueden cooperar con promotores proximales, mediante la apertura de la cromatina y el mantenimiento de un dominio competente para la transcripción, que confiere especificidad fisiológica y de tejido a los niveles de transcripción (66).

\section{Papel central de los receptores ILT3 e ILT4 en la regulación de la respuesta inmunitaria}

Mientras el ligando de ILT3 en las células T aún se desconoce, hay evidencia de que ILT4 ejerce sus efectos inmunomoduladores mediante la unión a diferentes moléculas clásicas y no clásicas $\mathrm{CMH}$ de clase I, tales como HLA-A, HLA-B y HLA-G1 $(69,70)$. Una vez ocurre la interacción entre el receptor y su ligando, los motivos ITIM permiten a los receptores inhibidores reclutar fosfatasas de tirosina SHP de clase 1020 fosfatasas de inositol SHIP 1 o 2. El reclutamiento de SHP 1 o 2 es responsable de la inhibición temprana de varias señales mediadas por la fosforilación de tirosinas (49), mientras que el reclutamiento de SHIP 10
2 es responsable por la inhibición de las señales dependientes de cinasas de fosfatidil-inositoltrifosfato y de fosfoinositil $(71,72)$. Estas fosfatasas citoplásmicas pueden desfosforilar los receptores inmunitarios activados que contienen dominios ITAM, conduciendo a su inactivación, lo cual resulta en una disminución en la capacidad de estímulo por parte de la célula presentadora de antígeno a la célula $T$, induciendo finalmente una inhibición en la respuesta de esta última $(73,74)$.

Se ha descrito, además, que el ILT4 interactúa con las moléculas HLA-G con una afinidad tres o cuatro veces más alta que con las moléculas $\mathrm{CMH}$ de clase I clásicas; por ello, se sugiere que esta interacción inhibe la activación de las células T, células NK y células mielomonocíticas en general $(73,74)$. Además, el ILT4 también compite efectivamente con CD8 por la unión a las moléculas CMH de clase I, con lo cual se bloquea la unión de CD8, permitiendo así una regulación negativa de la activación de las células T CD8, adicional al mecanismo ya descrito de reclutamiento de moléculas inhibidoras mediante los dominios ITIM (75).

Aunque la interacción MHC-ILT no está completamente estudiada, algunos reportes proponen también un modelo trimolecular hipotético que incluye las moléculas MHC-I e ILT4 en la célula presentadora de antígeno y el TCR de la célula T (figura 2) (76), siendo la interacción ILT4/ MHC-I antígeno-específica. $(77,78)$, lo cual podría explicarse por cambios en la conformación de la molécula MHC-I debido a la carga de determinados antígenos y que consecuentemente afecta la orientación de los sitios de unión de la molécula ILT en el dominio a3 y la $\beta 2$ microgobulina de la molécula MHC-I (79)

Estos mecanismos de inhibición por parte de los receptores inhibidores muestran la importancia de las células dendríticas en la inducción de la tolerancia específica de antígeno, y la generación de células $T$ reguladoras y T supresoras específicas de antígeno, perpetuando una cascada de eventos que regulan negativamente la alorreactividad de la célula $T(46,47)$.

Hasta ahora los datos sugieren que ILT3 es la pieza central en la supresión mediada por células T CD8+ y actúa como un master switch en la regulación de las respuestas de células T CD8+ y CD4+ (80). La importancia fisiológica y funcional de ILT3 e ILT4 se evidenció inicialmente mediante estudios de citometría de flujo, en los cuales se demostró que la preincubación de células de la 

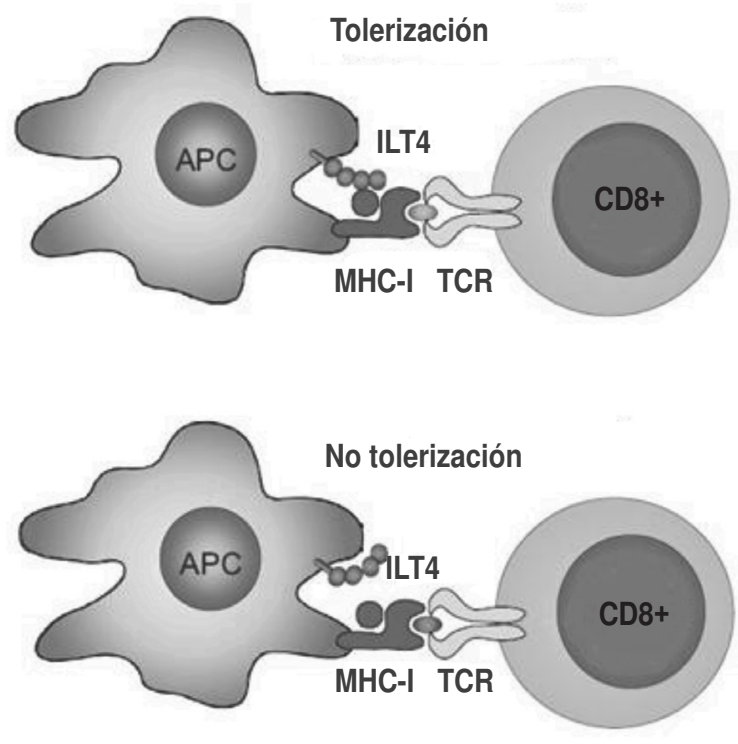

Figura 2. Inducción de tolerancia antígeno-específica. La interacción de ILT4 con el complejo antígeno/MHC I -TCR promueve la señal inhibidora (arriba) mientras que la unión de las moléculas MHC I con ciertos antígenos (abajo) impide su interacción con ILT4, evitando la inhibición de la respuesta inmunitaria.

Reproducción de autorización de: Li D, Chui C, 2009.

línea mielomonocítica KG1, las cuales presentan un fenotipo de células dendríticas inmaduras, con células T supresoras CD8+CD28-, aumentaba los niveles de expresión de ILT3 e ILT4 y una reducida capacidad de regular positivamente las moléculas coestimuladoras CD80 y CD86 (81).

Posteriormente, utilizando anti-ILT3 y anti-ILT4, se demostró que ILT3 e ILT4 eran responsables de la capacidad reducida de las células presentadoras de antígeno para estimular la proliferación de células $\mathrm{T}$ CD4+ en presencia de células $T$ supresoras CD8+CD28-. Estos anticuerpos disminuyeron la supresión, reestableciendo la capacidad de proliferación de las células CD4+. Además, el aumento de la expresión de ILT3 se asoció con inhibición del NF-kB (81,82). Posteriormente, se encontró que algunas células presentadoras de antígeno expuestas a células $\mathrm{T}$ supresoras CD8+CD28- tenían la capacidad de anergizar células $T$ supresoras CD4+CD25+, inhibiendo la respuesta de las células T CD4 vírgenes, lo cual sugiere que la presencia de células $T$, que convierten a las células presentadoras de antígeno en tolerogénicas, potencian también la diferenciación de células $T$ reguladoras CD4+CD25+ (44).

Algunas células T CD4+CD25- aloestimuladas con células dendríticas ILT3 $3^{\text {high ILT4 }} 4^{\text {high }}$ adquirieron una función reguladora y fenotipo característico de célula
T reguladoras $\mathrm{CD} 4+\mathrm{CD} 25+\mathrm{CD} 45 \mathrm{RO}+\mathrm{FOXP} 3+$. Al igual que las células $T$ supresoras CD8+CD28-, las células $T$ reguladoras CD4+CD25+ actuaron directamente sobre las células presentadoras de antígeno en forma dependiente del contacto e independiente de las citocinas, induciendo la regulación positiva de los receptores inhibidores (83). El hallazgo de que la exposición continuada de células $T$ a células presentadoras de antígeno alogénicas resulta tanto en la diferenciación de células Ts CD8+CD28- como de células T reguladoras $C D 4+C D 25+$, sugiere que las células T supresoras aloespecíficas CD8+CD28-inducen una "cascada supresora" (figura 3), en la cual las células presentadoras de antígeno se convierten en "tolerogénicas" y, posteriormente, éstas convierten a células T CD4 vírgenes en células T reguladoras CD4+CD25+.

Finalmente, las células presentadoras de antígeno convertidas en tolerogénicas por parte de células $T$ reguladoraspuedeninhibirtambiénlaalorreactividad de otras células T CD4, continuando así la cascada de supresión. Lo relevante de este modelo es el hallazgo de que las células presentadoras de antígeno con propiedades "tolerogénicas", basadas en la expresión aumentada de ILT3 e ILT4, disminuyen la respuesta de las células T específicas de antígeno (83).

Esta cascada de eventos puede proporcionar una unión entre los diferentes tipos de células $T$ reguladoras y, además, puede explicar el fenómeno de la "tolerancia infecciosa" que ocurre cuando la tolerancia hacia un aloinjerto es transferida adoptivamente de un receptor a otro (84). Aunque no se conocen exactamente los mecanismos moleculares involucrados en la generación de células $T$ reguladoras por la interacción con células dendríticas (85), se ha encontrado que la actividad enzimática de 2,3 indolamina dioxigenasa en células dendríticas estimuladas con lipopolisacáridos (LPS) contribuye a la expansión de células $T$ reguladoras (86). La 2,3 indolamina dioxigenasa cataliza la degradación del triptófano, disminuyendo el microambiente celular de este aminoácido esencial (87).

Recientemente se describió que, en un ambiente bajo en triptófano, se generan células dendríticas humanas, derivadas de monocitos, con una acentuada regulación positiva de los receptores ILT3 e ILT4 y una capacidad potenciada para inducir células T reguladoras CD4+CD25+FOXP3+ en forma dependiente de ILT3. Estos resultados 


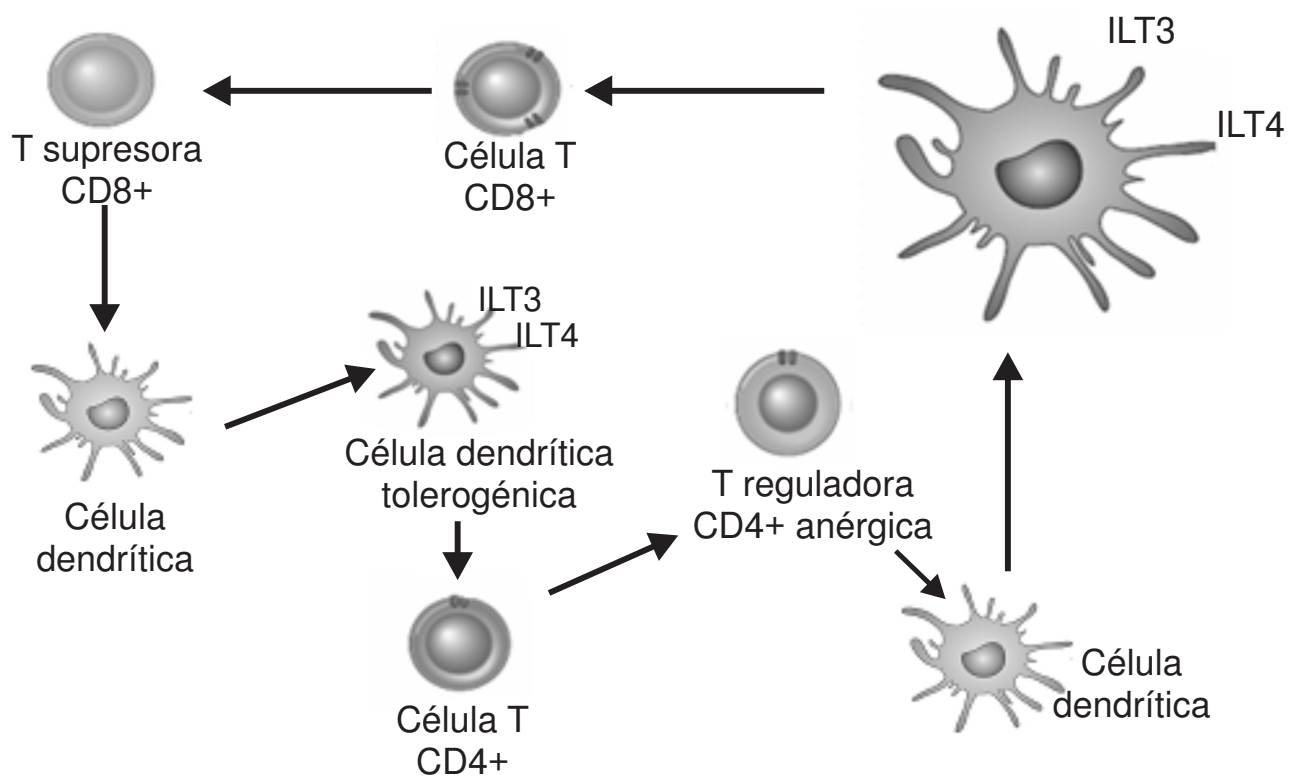

Figura 3. Papel de los receptores inhibidores en la "cascada supresora". Las células T supresoras inducen la regulación de los receptores ILT3 e ILT4 en células dendríticas, convirtiéndolas en tolerogénicas, las cuales son capaces de inducir la diferenciación de células T CD4+ a células T reguladoras. Éstas, a su vez, inducen la expresión de los receptores inhibidores en otras células dendríticas inductoras de un fenotipo supresor en células T CD8+.

Reproducción con autorización de: Suciu-Foca N, et al., 2003.

demuestran que los bajos niveles de triptófano establecen un microambiente regulador, no sólo para células $\mathrm{T}$, sino también para la diferenciación de células dendríticas (88).

In vivo, la regulación positiva de ILT3 e ILT4 adquiere gran relevancia en el contexto del trasplante de órganos, pues se ha demostrado que células $T$ supresoras CD8+CD28-CD27+ provenientes de pacientes con trasplante de corazón inhiben la regulación positiva de CD80 y CD86 en células presentadoras de antígeno provenientes del donante $(89,90)$ Este efecto inhibidor es restringido por las moléculas $\mathrm{CMH}$ de clase I, lo que demuestra la especificidad de antígeno de las células $T$ supresoras. Además, los estudios realizados en células transfectadas con plásmidos que contenían el gen de la luciferasa en el promotor de ILT3 e ILT4, demostraron que las células T supresoras de estos pacientes también inducían la regulación positiva de las moléculas ILT3 e ILT4, en las células presentadoras de antígeno provenientes del donante, donde nuevamente se encontró que la transcripción de estas dos moléculas era restringida por las moléculas $\mathrm{CMH}$ de clase I del donante (83).

Recientemente, nuestro grupo demostró in vivo que, en pacientes con transplante de riñón con supervivenciasalargoplazoy bajo brevesesquemas de inmunosupresión, los porcentajes de células dendríticas circulantes ILT3+ e ILT4+ estaban aumentados, en comparación con pacientes en rechazo crónico y pacientes con supervivencias a corto plazo, lo cual sugiere que el rechazo puede ser facilitado por la ausencia de algunas propiedades reguladoras en estos pacientes, convirtiendo a las células dendríticas ILT3+ e ILT4+ en posibles biomarcadores de un proceso de regulación que contribuye a la supervivencia a largo plazo en ausencia de rechazo (91)

Todos estos hallazgos reiteran la importancia fisiológica y funcional de estos receptores inhibidores, no sólo in vitro sino in vivo, durante la anergización de la célula $T$, la diferenciación de células $T$ reguladoras, T supresoras y la creación, en general, de una retroalimentación inhibidora que permite regular negativamente "alorrespuestas" específicas de antígeno.

\section{Perspectivas}

Con base en los hallazgos descritos, el concepto emergente es que las células dendríticas que expresan los receptores inhibidores ILT3 e ILT4 pueden utilizarse para la inducción de tolerancia inmunológica en campos como la inmunología de trasplantes y las enfermedades autoinmunitarias. Los datos sugieren que la tolerancia a trasplantes 
Cuadro 1. Términos y definiciones en inmunología de trasplantes, immunorregulación y biología de células dendríticas.

\section{Término}

Activación por dos señales

Anergia de la célula T

Células $\mathrm{T}$ reguladoras $(\mathrm{Tr})$

Células $T$ reguladoras

FOXP3+CD4+CD25+

Célula T supresora (Ts)

Complejo mayor de histocompatibilidad $(\mathrm{CMH})$

Célula dendrítica precursora (preDC)

Inmunosupresión

Rechazo

Proteasoma

Trasplante
Significado

La célula T requiere tanto de la unión del complejo MHC-péptido y el TCR (señal 1) como de la señal coestimuladora generada por moléculas de la familia B7 expresadas en la APC y el CD28 en la célula T (señal 2) para su completa activación.

El estado de débil respuesta de la célula T frente a estímulos antigénicos, puede ser inducido por el estímulo antigénico en ausencia de la señal coestimuladora.

Es una subpoblación de células T que secreta altos niveles de IL-10 y que regula negativa mente las respuestas celulares de tipo Th1 in vitro e in vivo por un mecanismo dependiente de contacto y mediado por la secreción de interleucinas reguladoras, como IL-10 y TGF $\beta 1$.

Es una población de células T reguladoras de presentación natural que se desarrolla en el timo pero también puede ser generada en el transcurso de una respuesta inmunitaria; expresan altos niveles del factor de transcripción FOXP3 en el núcleo e inhiben la respuesta de proliferación de células T mediante un mecanismo dependiente del contacto.

Es la célula productora de citocinas o factores supresores que bloquean la activación de otras células T efectoras. Las células T supresoras son caracterizadas por el fenotipo CD8+CD28-

Son moléculas polimórficas de superficie presentes en la superficie celular, que actúan como moléculas de presentación de péptidos para el reconocimiento por las células $T$. Existen dos clases de moléculas del $\mathrm{CMH}$ estructuralmente distintas. Las moléculas de clase I o CMH I están presentes en la mayoría de las células nucleadas y se unen a péptidos derivados de proteínas del citosol y son reconocidas por células T CD8+. Las moléculas de clase II o $\mathrm{CMH}$ II están restringidas a las APC, se unen a péptidos derivados de proteínas que han sido endocitadas y son reconocidas por las células T CD4+.

Es un predecesor inmediato de una célula dendrítica que, en estado de reposo, no tiene la apariencia o función de una célula dendrítica. Las pre-células dendríticas adquieren la morfología y capacidad estimuladora mediante un estímulo microbiano o inflamatorio.

Es el uso de fármacos en la práctica clínica y modelos experimentales para evitar o revertir el rechazo. Estos medicamentos inhiben la fase de activación y proliferación de linfocitos $T$ mediante la reducción, la desviación del tráfico de linfocitos o el bloqueo de las vías de activación del linfocito.

Es la activación del sistema inmunitario frente a las moléculas del $\mathrm{CMH}$ no propias presentes en el injerto. Esta respuesta está asociada con daño al tejido mediado por inflamación crónica, aloanticuerpos y alteraciones vasculares, causadas por la inmunidad mediada por células T y $B$.

Es un complejo enzimático de actividad proteolítica que se encuentra en la mayoría de las células y que genera, a partir de las proteínas del citosol, los péptidos que se unen a las moléculas de clase I del $\mathrm{CMH}$

Es el proceso por el cual se toman células, tejidos u órganos de un individuo (donante) y se colocan (generalmente) en otro individuo diferente (receptor) o en algunos casos en el mismo individuo. También se denomina injerto.

De acuerdo con la relación donante-receptor, se han definido cuatro tipos de trasplantes:

1) autólogo: injerto realizado con células o tejidos del mismo individuo;

2) singénico: injerto realizado entre dos individuos genéticamente idénticos;

3) alogénico: injerto realizado entre dos individuos genéticamente diferentes, pero de la misma especie, y

4) xenogénico: injerto realizado entre individuos de especies diferentes. alogénicos puede ser inducida por medio del tratamiento con ILT3 soluble.

A diferencia del sILT4, el sILT3 muestra una fuerte actividad inhibidora (92), lo cual confirma que ILT3 tiene efectos tanto intracelulares como extracelulares, mientras que ILT4 sólo ejerce efectos inhibidores a nivel intracelular, bloqueando la diferenciación de la célula presentadora de antígeno. El sILT3, además, inhibe la "alorreactividad" de las células T CD8+ en células $\mathrm{T}$ supresoras antígeno-específicas Foxp3+ y no induce inmunosupresión inespecífica debido a que actúa solamente sobre células T activadas (93). 
Es posible que el pretratamiento de órganos potenciales para trasplantes con agentes que induzcan la regulación positiva de ILT3 e ILT4 en las células presentadoras de antígeno del donante - el pretratamiento del receptor con células presentadoras de antígeno del donante, puedan prevenir el rechazo de aloinjertos por células $T$ CD4+ alorreactivas y la iniciación de una cascada supresora. Asimismo, el tratamiento de la médula ósea de los receptores con agentes que induzcan la regulación positiva de ILT3 e ILT4, podría prevenir el desarrollo de la enfermedad del injerto contra huésped (44). Se ha demostrado que el tratamiento con SILT3 (o ILT3 Fc) en ratones hu-NOD/SCID, previene la enfermedad de injerto xenogénico contra huésped (94) y suprime la respuesta de las células $T$ frente a trasplantes alogénicos de islotes pancreáticos humanos (95).

Por otra parte, la progresión de la respuesta en enfermedades autoinmunitarias pudiera ser prevenida por el tratamiento de pacientes con células dendríticas autólogas ILT3 $3^{\text {high }}$ ILT4 $4^{\text {high }}$ que han procesado ex vivo el autoantígeno en cuestión. Alternativamente, la administración de sILT3 pudiera convertir las células T autorreactivas en células $T$ supresoras, las cuales pueden iniciar y mantener la cascada de eventos inmunosupresores. Similarmente, el tratamiento basado en la utilización de células T supresoras activadas in vitro en presencia de sILT3, podría inhibir la autoinmunidad (83).

También, se le ha dado importancia a estos receptores inhibidores en la infección con virus de la inmunodeficiencia humana/síndrome de inmunodeficiencia adquirida ( $\mathrm{VIH} / \mathrm{sida})$, pues se ha demostrado que los monocitos de pacientes infectados con $\mathrm{VIH}$ expresan niveles significativamente más altos de ILT4 que los monocitos provenientes de controles sanos. Además, el aumento de la expresión de ILT4 en los monocitos expuestos a suero de pacientes infectados con $\mathrm{VIH}$, resulta en la inhibición de la activación y la proliferación de células T CD4+ (90). Este hallazgo sugiere que algunos medicamentos podrían bloquear esas moléculas, pudiendo tener un valor terapéutico significativo para el tratamiento de estos pacientes.

Se ha demostrado, además, que pacientes con cáncer poseen porcentajes de ILT3 más altos y que el sILT3 inhibe la reactividad de la célula T in vitro. Este efecto inhibidor fue parcialmente suprimido por anticuerpos monoclonales anti-ILT3 o por la depleción de ILT3 presente en suero, lo cual sustenta la hipótesis de que ILT3 es un factor supresor. Estos datos, junto a los encontrados en un modelo de ratones "humanizados" (hu-SCID) en el cual el ILT3 de membrana y el ILT3-Fc inhibían el rechazo de aloinjertos tumorales, indican que ILT3 puede contribuir al escape de los tumores de la vigilancia del sistema inmunitario (80). Por lo tanto, el progreso en el entendimiento de los receptores inhibidores ILT3 e ILT4 es crucial para lograr la modulación de la respuesta inmunitaria en trasplantes, autoinmunidad, enfermedades infecciosas y cáncer (43).

\section{Conclusiones}

La biología, la habilidad inmunorreguladora y las aplicaciones clínicas de las células dendríticas han sido ya revisadas extensivamente. No obstante, mucho de lo que hemos aprendido acerca del desarrollo y función de las células dendríticas se ha basado en estudios y hallazgos de células propagadas in vitro, a partir de precursores de médula ósea de ratón, de precursores humanos monocíticos y de células dendríticas provenientes de sangre periférica humana (96-97).

Hoy en díA, uno de los tópicos más interesantes en el estudio de las células dendríticas es su potencial para inducir tolerancia hacia antígenos específicos, con el objeto de utilizarlas como tratamiento para el rechazo de aloinjertos y controlar alteraciones inmunitarias. El protagonismo de los receptores inhibidores ILT3 e ILT4 en la actividad inmunoreguladora de la célula dendrítica, se demuestra porque su presencia potencia notablemente la inducción de una cascada inmunosupresora que regula respuestas inmunitarias específicas de antígeno.

Aunque aún quedan muchas dudas por resolver acerca de la influencia de estos receptores en la biología, funcionalidad y efecto sobre las células dendríticas tolerogénicas y otras poblaciones celulares, es probable que ellas puedan ser utilizadas en investigación de trasplantes, como marcadores asociados a respuestas débiles y estados parciales de tolerancia en pacientes con trasplante, lo que señalaría una novedosa estrategia para identificar aquellos pacientes que han desarrollado estados de tolerancia hacia el aloinjerto, lo que, a su vez, también abriría una ventana que permitiría, eventualmente, prescindir cada vez más de los fármacos inmunosupresores.

\section{Conflicto de intereses}

Los autores declaran no tener conflicto de intereses. 


\section{Financiación}

La financiación de los resultados discutidos en esta revisión de tema fueron soportados por la Vicerrectoría de Investigación, Universidad de Antioquia y con recursos propios del Grupo de Inmunología Celular e Inmunogenética (GICIG), Facultad de Medicina, Universidad de Antioquia.

\section{Referencias}

1. Penn I. Post-transplant malignancy: The role of immunosuppression. Drug Saf. 2000;23:101-7.

2. Ehser S, Chuang J, Kleist C, Sandra-Petrescu F, lancu M, Wang D, et al. Suppresive dendritic cells as a tool for controlling allograft rejection in organ traspalntation: Promises and difficulties. Hum Immunol. 2008;69:156-73.

3. Morelli E, Thompson W. Tolerogenic dendritic cells and the quest for transplant tolerance. Nat Rev Immunol. 2007;7:610-21

4. Sykes M. Immune tolerance: Mechanism and application in clinical Transplantation. J Intern Med. 2007;262:288-310.

5. Banchereau J, Steinman R. Dendritic cells and the control of immunity. Nature. 1998;392:245-52.

6. Lu L, Rudert WA, Qian S, McCaslin D, Fu F, Rao AS, et al. Growth of donor-derived dendritic cells from the bone marrow of murine liver allograft recipients in response to granulocyte/ macrophage colony-stimulating factor. J Exp Med. 1995;182:379-87.

7. Lutz MB, Schuler G. Immature, semi-mature and fully mature dendritic cells: Which signals induce tolerance or immunity? Trends Immunol. 2002;23:445-9.

8. Hugues S, Fetler L, Bonifaz L, Helft J, Amblard F, Amigorena S. Distinct $\mathrm{T}$ cell dynamics in lymph nodes during the induction of tolerance and immunity. Nat Immunol. 2004;5:1235-42.

9. Munn DH, Zhou M, Attwood JT, Bondarev I, Conway SJ, Marshall B, et al. Prevention of allogeneic fetal rejection by tryptophan catabolism. Science. 1998;281:1191-3.

10. Oh GS, Pae HO, Choi BM, Chae SC, Lee HS, Ryu DG, et al. 3-hydroxyanthranilic acid, one of metabolites of tryptophan via indoleamine 2,3-dioxygenase pathway, suppresses inducible nitric oxide synthase expression by enhancing heme oxygenase-1 expression. Biochem Biophys Res Commun. 2004;320:1156-6.

11. Reid S, Penna G, Adorini L. The control of $T$ cell responses by dendritic cell subsets. Curr Opin Immunol. 2000;12:114-21.

12. Steinman RM, Cohn ZA. Identification of a novel cell type in peripheral lymphoid organs of mice. I. Morphology, quantitation, tissue distribution. J Exp Med. 1973;137: 1142-62.

13. Coquerelle $\mathbf{C}$, Moser M. Are dendritic cells central to regulatory T cell function? Immunol Lett. 2008;119:12-6.

14. Dzionek A, Inagaki Y, Okawa K, Nagafune J, Rock J, Sohma Y, et al. Plasmacytoid dendritic cells: From specific surface markers to specific cellular functions. Hum Immunol. 2002;63:1133-48.
15. Shi H, Ge J, Fang W, Yao K, Sun A, Huang R, et al. Peripheral-blood dendritic cells in men with coronary heart disease. Am J Cardiol. 2007;100:593-7.

16. Shortman, K, Naik SH. Steady-state and inflammatory dendritic-cell development. Nat Rev Immunol. 2007;7:1930

17. Naik, S. Sathe, P, Park H, Metcalf D, Proietto A, Dakic $A$, et al. Development of plasmacytoid and conventional dendritic cell subtypes from single precursor cells derived in vitro and in vivo. Nat Immunol. 2007;8:1217-26.

18. Ardavin C. Origin, precursors and differentiation of mouse dendritic cells. Nat Rev Immunol. 2003;3:582-90.

19. Henri S, Siret C, Machy P, Kissenpfennig A, Malissen $B$, Leserman L. Mature DC from skin and skin draining LN retain the ability to acquire and efficiently present targeted antigen. Eur J Immunol. 2007; 37:1184-93.

20. Asselin-Paturel C, Boonstra A, Dalod M, Durand I, Yessaad N, Dezutter-Dambuyant C, et al. Mouse type I IFN producing cells are immature APCs with plasmacytoid morphology. Nat Immunol. 2001;2:1144-50.

21. Liu YJ. IPC: Professional type 1 interferon-producing cells and plasmacytoid dendritic cell precursors. Annu Rev Immunol. 2005;23:275-306.

22. Granuccia F, Zanonia I, Ricciardi-Castagnol P. Central role of dendritic cells in the regulation and deregulation of immune responses. Cell Mol Life Sci. 2008;65:1683-97.

23. Ehser S, Chuang J, Kleist C, Sandra-Petrescu F, lancu M, Wang D, et al. Suppressive dendritic cells as a tool for controlling allograft rejection in organ transplantation: Promises and difficulties. Hum Immunol. 2008;69:165-73.

24. Cella M, Facchetti F, Lanzavecchia A, Colonna M. Plasmacytoid dendritic cells activated by influenza virus and CD40L drive a potent TH1 polarization. Nat Immunol. 2000;1:305-10.

25. Larsson $\mathbf{M}$, Fonteneau J, Bhardwaj N. Dendritic cells resurrect antigens from dead cells. Trends Immunol. $2001 ; 22: 141-8$.

26. Wu L, Dakic A. Development of dendritic cell system. Cell Mol Immunol. 2004;1:112-28.

27. Sato K, Yamashita N, Baba M, Matsuyama T. Modified myeloid dendritic cells act as regulatory dendritic cells to induce anergic and regulatory $T$ cells. Blood. 2003;101:3581-9.

28. Trombetta ES, Mellman I. Cell biology of antigen processing in vitro and in vivo. Annu Rev Immunol. 2005;23:975-1028.

29. Pfeifer J, Wick MJ, Roberts R, Findlay K, Normark SJ, Harding CV. Phagocytic processing of bacterial antigens for class I MHC presentation to T cells. Nature. 1993;361:359-62.

30. Piemonti L, Monti P, Allavena P, Sironi M, Soldini L, Leone BE, et al. Glucocorticoids affect human dendritic cell differentiation and maturation. J Immunol. 1999;162: 6473-81.

31. Banchereau J, Steinman RM. Dendritic cells and the control of immunity. Nature. 1998;392:245-52.

32. Walunas TL, Lenschow DJ, Bakker CY, Linsley PS, Freeman GJ, Green JM, et al. CTLA-4 can function as a 
negative regulator of T cell activation. Immunity. 1994;1:40513.

33. Andre N. T-cell activation through the antigen receptor. Part I: Signaling components, signaling pathway and integration at the $\mathrm{T}$ cell antigen receptor synapse. J Allergy Clin immunol. 2002;109:758-70.

34. Le Moine A, Goldman M, Abramowics D. Multiple pathways to allograft rejection. Transplantation. 2002;9:1373-81.

35. Game DS, Lechler RI. Pathways of allorecognition: Implications for transplantation tolerance. Transpl Immunol. 2002;10:101-8.

36. Ankit Bharat, Mohanakumar T. Allopeptides and the alloimmune response. Cell Immunol. 2007;248:31-43.

37. Schwartz R. T cell anergy. Annu Rev Immunol. 2003;21: 305-34

38. Mahnke K, Johnson T, Ring S, Enk A. Tolerogenic dendritic cells and regulatory T cells: A two way relationship. J Dermatol Sci. 2007;46:159-67.

39. Chambers C, Allison P. Costimulatory regulation of $\mathrm{T}$ cell function. Curr Opin Cell Biol. 1999;11:203-10.

40. Nurieva R, Thomas S, Nguyen T, Martín-Orozco N, Wang $\mathbf{Y}$, Kaja M, et al. T cell tolerance or function is determined by combinatorial costimulatory signals. EMBO J. 2006; 25:2623-33.

41. Vacca C, Fallarino F, Perruccio K, Orabona C, Bianchi R, Gizzi S. CD40 ligation prevents onset of tolerogenic properties in human dendritic cells treated with CTLA-4-IG. Microbes Infect. 2005;7:1040-8.

42. Steinman RM, Hawiger D, Nussenzweig MC. Tolerogenic dendritic cells. Annu Rev Immunol. 2003;2:685-711.

43. Cortesini N, Piazza N, Ho E, Ciubotarui R, LeMault $\mathbf{J}$, Favera $\mathbf{R}$, et al. Distinct mRNA microarray profiles of tolerogenic dendritic cells. Hum Immunol. 2000;62:1065-72.

44. Manavalan JS, Rossi PC, Vlad G, Piazza F, Yarilina A, Cortesini R, et al. High expression of ILT3 and ILT4 is a general feature of tolerogenic dendritic cells. Transpl Immunol. 2003;11:245-58.

45. Suciu-Foca N, Cortesini R. Central role of ILT3 in the T suppressor cell cascade. Cell Immunol. 2007;248:59-67.

46. Subudhi S, Alegre M. The balance of immune responses: Costimulation versus coinhibition. J Mol Med. 2005;83: 193-202.

47. Cortesini N. Molecular characterization of allospecific $\mathrm{T}$ suppressor tolerogenic dendritic cells: Review. Int Immunopharmacol. 2005;5:7-11.

48. Scharenberg A. The inhibitory receptor superfamily: Potential relevance to atopy. Curr Opin Immunol 1999;11:621-5.

49. Long E. Regulation of immune responses through inhibitory receptors. Annu Rev Immunol. 1999;17:875-904.

50. Cella M, Dohring C, Samaridis J, Dessing M, Brockhaus M, Lanzavecchia A, et al. A novel inhibitory receptor ILT3 expressed on monocytes, macrophages, and dendritic cells involved in antigen processing. J Exp Med. 1997; 185:1743-51.

51. Fanger NA, Cosman D, Peterson L, Braddy SC, Maliszewski CR, Borges L. The MHC class I binding proteins LIR-1 and LIR-2 inhibit Fc receptor-mediated signaling in monocytes. Eur J Immunol. 1998;28:3424-34.

52. Colonna M, Nakajima H, Cella M. A family of inhibitory and activating Ig-like receptors that modulate function of lymphoid and myeloid cells. Immunology. 2000;12:121-7.

53. Jua X, Hackera C, Schererb B, Redeckeb V, Bergerc T, Schulerc G, et al. Immunoglobulin-like transcripts ILT2, ILT3 and ILT7 are expressed by human dendritic cells and downregulated following activation. Gene. 2004;331: 159-64.

54. Borges L, Fanger N, Cosman D. Interactions of LIRs, a family of immunoreceptors expressed in myeloid and lymphoid cells, with viral and cellular MHC class I antigens. Curr Top Microbiol Immunol. 1999;244:123-36.

55. Colonna M, Nakajima $\mathbf{H}$, Cella $\mathbf{M}$. A family of inhibitory and activating $\mathrm{Ig}$-like receptors that modulate function of lymphoid and myeloid cells. Semin Immunol. 2000;12:121-7.

56. Wagtmann N, Rojo S, Eichler E, Mohrenweiser H, Long EO. A new human gene complex encoding the killer cell inhibitory receptors and related monocyte-macrophage receptors. Curr Biol. 1997;7:615-8.

57. Colonna M, Navarro F, Bellon T, Llano M, García $\mathbf{P}$, Samaridis $\mathrm{J}$, et al. A common inhibitory receptor for major histocompatibility complex class I molecules on human lymphoid and myelomonocytic cells. J Exp Med. 1997;186:1809-18.

58. Papanikolaou N, Vasilescu E, Suciu-Foca N. Novel single nucleotide polymorphisms in the human immune inhibitory immunoglobulin-like T cell receptor type 4. Hum Immunol. 2004;65:700-5.

59. Chang C, Silvia E, Ho H, Vlad G, Suciu-Foca N, Vasilescu R. Polymorphism and linkage disequilibrium of immunoglobulin-like transcript 3 gene. Hum Immunol. 2008;69:284-90.

60. Samaridis J, Colonna M. Cloning of novel immunoglobulin superfamily receptors expressed on human myeloid and lymphoid cells: Structural evidence for new stimulatory and inhibitory pathways. Eur J Immunol. 1997;27:660-5

61. Nakajima H, Samaridis J, Angman L, Colonna M. Human myeloid cells express an activating ILT receptor ILT1 that associates with $\mathrm{Fc}$ receptor gamma-chain. J Immunol. 1999;162:5-8.

62. Banham AH, Colonna M, Cella M, Micklem KJ, Pulford Willis AC, Mason DY. Identification of the CD85 antigen as ILT2, an inhibitory MHC class I receptor of the immunoglobulin superfamily. J Leukoc Biol. 1999;65:841-5.

63. Fedoric B, Krishnanv R. Rapamycin down-regulates the inhibitory receptors ILT2, ILT3, ILT4 on human dendritic cells and yet induces $T$ cell hyporesponsiveness independent of FoxP3 induction. Immunol Lett. 2008;120:49-56.

64. Colonna M, Nakajima H, Cella M. Inhibitory and activating receptors involved in immune surveillance by human NK and myeloid cells. J Leukoc Biol. 1999;66:5718-22

65. Nakajima H, Asai A, Okada A, Ping L, Hamajima F, Sata $\mathbf{T}$, et al. Transcriptional regulation of ILT family receptors. $J$ Immunol. 2003;171:6611-20.

66. Agarwal S, Rao A. Modulation of chromatin structure regulates cytokine gene expression during $\mathrm{T}$ cell differentiation. Immunity.1998;9:765-75. 
67. Fields P, Kim T, Flavell R. Cutting edge: Changes in histone acetylation at the IL-4 and IFN- $\gamma$ loci accompany Th1/Th2 differentiation. J Immunol. 2002;169:647-50.

68. Narlikar G, Fan H, Kingston E. Cooperation between complexes that regulate chromatin structure and transcription. Cell. 2002;108:475-87.

69. Allan S, Colonna M, Lanier LL, Churakova TD, Abrams JS, Ellis SA, et al. Tetrameric complexes of human histocompatibility leukocyte antigen (HLA)-G bind to peripheral blood myelomonocytic cells. J Exp Med. 1999;189:1149-56.

70. Le Rond S, Azema C, Krawice-Radanne I, Durrbach A, Guettier C, Carosella ED, et al. Evidence to support the role of HLA-G5 in allograft acceptance through induction of immunosuppressive/regulatory $\mathrm{T}$ cells. $\mathrm{J}$ Immunol. 2006;176:3266-76

71. Scharenberg AM, El-Hillal O, Fruman DA, Beitz LO, Li Z, Lin S, et al. Phosphatidylinositol-3,4,5- trisphosphate (Ptdlns-3,4,5-P3)/Tec kinase-dependent calcium signaling pathway: a target for SHIP-mediated inhibitory signals. EMBO J. 1998;17:1961-72.

72. Bolland S, Pearse RN, Kurosaki T, Ravetch JV. SHIP modulates immune receptor responses by regulating membrane association of Btk. Immunity. 1998;8:509-16.

73. Colonna M, Samaridis J, Cella M, Angman L, Allen RL, O'Callaghan CA, et al. Human myelomonocytic cells express an inhibitory receptor for classical and nonclassical MHC class I molecules. J Immunol. 1998;160:3096-100

74. Ravetch JV, Lanier LL. Immune inhibitory receptors. Science. 2000;290:84-9.

75. Shiroishi M, Tsumoto K, Amano K, Shirakihara Y, Colonna M, Braud VM, et al. Human inhibitory receptors Ig-like transcript 2 (ILT2) and ILT4 compete with CD8 for $\mathrm{MHC}$ class I binding and bind preferentially to HLA-G. Proc Natl Acad Sci USA. 2003;100:8856-61

76. Chui C, Li D. Role of immnunoglobulin-like-transcript family receptors and their ligands in supresor T-cell-induced dendritic cell tolerization. Hum Immunol. 2009;70:686-91.

77. Li D, Wang L, Yu L, Freundt EC, Jin B, Screaton GR, et al. Ig-like transcript 4 inhibits lipid antigen presentation through direct CD1d interaction. J Immunol. 2009;182:1033-40.

78. Lichterfeld M, Kavanagh DG, Williams KL, Moza B, Mui SK, Miura T, et al. A viral CTL escape mutation leading to immunoglobulin-like transcript 4-mediated functional inhibition of myelomonocytic cells. J Exp Med. 2007;204:2813-24.

79. Koch M, Stronge VS, Shepherd D, Gadola SD, Mathew B, Ritter G, et al. The crystal structure of human CD1d with and without alpha galactosylceramide. Nat Immunol. 2005;6:819-26.

80. Vlad G, Cortesini R, Suciu-Foca N. CD8 T suppressor cells and the ILT3 master switch. Hum Immunol. 2008;69:681-6.

81. Chang CC, Ciubotariu R, Manavalan JS, Yuan J, Colovai Al, Piazza F, et al. Tolerization of dendritic cells by $T(s)$ cells: The crucial role of inhibitory receptors ILT3 and ILT4. Nat Immunol. 2002;3:237-42.

82. Li J, Liu Z, Jiang S, Cortesini R, Lederman S, SuciuFoca N. T suppressor lymphocytes inhibit NF-kappa
B-mediated transcription of CD86 gene in APC. J Immunol. 1999;163:6386-92.

83. Suciu-Foca N, Manavalan J, Cortesini R. Generation and function of antigen-specific suppressor and regulatoryT cells. Transpl Immunol. 2003;11:235-44.

84. Cella M, Dohring C, Samaridis J, Dessing M, Brockhaus M, Lanzavecchia A, et al. A novel inhibitory receptor ILT3 expressed on monocytes, macrophages, and dendritic cells involved in antigen processing. J Exp Med. 1997;185:174351.

85. Akbar A, Vuckmanovic-Stejic L, Taams LS, Macallan D. The dynamic co-evolution of memory and regulatory CD4+ T cells in the periphery. Nat Rev Immunol. 2007;7:231-7.

86. Hill M, Tanguy-Royer P, Chauveau K, Asghar C, Tesson L, Lavainne L, et al. IDO expands human CD4+CD25high regulatory $T$ cells by promoting maturation of LPS treated dendritic cells. Eur J Immunol. 2007;37:3054-62.

87. Mellor A, Munn D. IDO expresión by dendritic cells: Tolerance and tryptophan catabolism. Nat Rev Immunol. 2004:4:762-74.

88. Brenk M, Scheler M, Koch S, Neuman J, Takikawa O, Häcker J, et al. Tryptophan deprivation induces Inhibitory receptors ILT3 and ILT4 on dendritic cells favoring the induction of human CD4+CD25+Foxp3+ regulatory cells. J Immunol. 2009;183:145-54.

89. Ciubotariu R, Vasilescu R, Ho E, Cinti P, Cancedda C, Poli L, et al. Detection of T suppressor cells in patients with organ allografts. Hum Immunol. 2001;62:15-20.

90. Cortesini R, Renna-Molajoni E, Cinti P, Pretagostini R, Ho E, Rossi P, et al. Tailoring of immunosuppression in renal and liver allograft recipients displaying donor specific T-suppressor cells. Hum Immunol. 2002;63:1010-8.

91. Arboleda J. Papel de las células dendríticas tolerogénicas en la sobrevida a largo plazo del aloinjerto renal (tesis). Medellín: Universidad de Antioquia; 2009.

92. Beinhauer BG, McBride JM, Graf $P$, Pursch E, Bongers M, Rogy M, et al. Interleukin 10 regulates cell surface and soluble LIR-2 (CD85d) expression on dendritic cells resulting in $\mathrm{T}$ cell hyporesponsiveness in vitro. Eur $\mathrm{J}$ Immunol. 2004;34:74-80.

93. Kim-Schulze S, Scotto L, Vlad G, Piazza F, Lin H, Zhuoru $\mathrm{L}$, et al. Recombinant Ig-Like transcript 3-Fc modulates $T$ cell response via induction of Th anergy and differentiation of Cd8+ T suppressor cells. J Immunol. 2006;176:2790-8.

94. Vlad G, D'Agatti V, Zhang Q, Liu Z, Ho E, Mohanakumar T, et al. Immunolobulin-like transcript 3-Fc suppresses T-cell responses to allogenic human islet transpalts in hu-NOD/ SCID mice. Diabetes. 2008:57:1878-86.

95. Vlad G, Stokes M, Liu Z, Chang C, Sondermeijer H, Vasilescu $\mathrm{E}$, et al. Suppression of xenogenic graftversus-host disease by treatment with immunoglobulin-like transcript 3-Fc. Hum Immunol. 2009;70:663-9

96. Vlad G, Liu, Zhang Q, Cortesini R, Suciu-Foca N. Immunosuppressive activity of recombinant ILT3. Int Immunopharmacol. 2006;6:1889-94.

97. Solari M, Thomson A. Human dendritic cells and transplant outcome. Transplantation. 2008;85:1513-22. 